\title{
Synthesis of a truncated $M_{\mathrm{r}} 46000$ mannose 6-phosphate receptor that is secreted and retains ligand binding
}

\author{
Martin WENDLAND, Annette HILLE, Gerhard NAGEL, Abdul WAHEED, Kurt von FIGURA \\ and Regina POHLMANN* \\ Universität Göttingen, Biochemie II, Gosslerstrasse 12d, D-3400 Göttingen, Federal Republic of Germany
}

\begin{abstract}
The $M_{\mathrm{r}} 46000$ mannose 6-phosphate receptor is an integral membrane protein with its ligand-binding site in the ectoplasmic domain. By site-directed mutagenesis, a stop codon was introduced in the receptor cDNA at the border between the ectoplasmic and membrane-spanning domain. The truncated receptor was expressed in three different systems, Xenopus oocytes, COS cells and BHK-21 cells. In all three systems the truncated receptor behaved as a soluble protein. In oocytes only small amounts of the truncated receptor were secreted within $48 \mathrm{~h}$ after synthesis. Accumulation of endoglucosaminidase $\mathrm{H}$-sensitive forms of the truncated receptor in oocytes suggested that exit from the endoplasmic reticulum was slowed down. In COS and BHK-21 cells, the truncated receptor was secreted and, as for wild-type receptor, most of the $N$-linked oligosaccharides were processed to complex forms. Both the intracellularly-retained (oocytes) and the secreted (COS and BHK-21 cells) truncated receptors bound to phosphomannan-Sepharose in a mannose6-phosphate-dependent manner. Using chemical cross-linking, the truncated receptor was shown to be secreted as a homodimer.
\end{abstract}

\section{INTRODUCTION}

Mannose 6-phosphate receptors bind newly-synthesized lysosomal enzymes in the Golgi apparatus and direct their transport to prelysosomal organelles where, due to the low $\mathrm{pH}$,' the receptor-ligand complexes dissociate. The lysosomal enzymes are transported to lysosomes, whereas the mannose 6-phosphate receptors recycle to the Golgi apparatus (for review see [1]).

So far, two distinct mannose 6-phosphate receptors have been isolated. The smaller of the two receptors (MPR-46) has an apparent size of $46000 \mathrm{Da}$. The larger of the two receptors (M6P/IGF II receptor) has an apparent molecular mass of $215000 \mathrm{Da}$ and binds mannose-6-phosphate-containing ligands and insulin-like growth factor II (IGF II) [2]. Both receptors are integral membrane proteins $[3,4]$. Hydropathy profiles of the deduced amino acid sequences and limited proteolysis studies reveal a single membrane-spanning segment dividing a short $C$-terminal cytoplasmic domain from a larger, ectoplasmic $N$-terminal domain. The ligandbinding site is located in the ectoplasmic domain of the receptors.

MPR-46 exists in membranes as a homodimer [4]. Dimerization of the receptor has been correlated with its ability to bind ligands (A. Waheed, A. Hille, Junghans \& $\mathrm{K}$. von Figura, unpublished work). The subunits interact by noncovalent bonds, since most of them can be dissociated by SDS under non-reducing conditions [5].

In the present study we used a truncated form of the human MPR-46 to show that the ectoplasmic domain alone folds correctly and assembles to dimers which are able to bind mannose 6-phosphate.

\section{MATERIALS AND METHO!S}

\section{Construction of expression vectors}

The EcoRI ends of P29 cDNA [6] were filled using Klenow polymerase and subcloned into the $S m a \mathrm{I}$ site of the vector pSVL resulting in pSVL-P29. To delete the $5^{\prime}$ untranslated region, pSVL-P29 was linearized with XhoI and treated with exonuclease III followed by mung bean nuclease according to the manufacturer's protocol (Stratagene, Heidelberg, Germany). For subcloning of the $5^{\prime}$ deleted insert, the nuclease-treated vector was digested with Sst I, the blunt-end-Sst I fragment containing the insert P29 $\Delta 5^{\prime}$ was isolated and inserted into an $X b a \mathrm{I}$-blunted, SstI-digested pSVL resulting in pSVL-P29 $\Delta 5^{\prime}$. The $5^{\prime}$ end of the insert was determined by sequencing. For construction of pBHE-P29 $\Delta 5^{\prime}$, pSVL-P29 $\Delta 5^{\prime}$ was digested with $X h o I$ and Sst I, and the insert was blunted and subcloned into the SmaI site of pBHE.

Oligonucleotide-directed mutagenesis of the codon for Leu-192 in P29 to ochre was done in M13mp18 ssDNA according to Nakamaye \& Eckstein [7]. To construct pSVL-P29 $\Delta 5^{\prime} / 192$ ochre and pBHE-P29 $\Delta 5^{\prime} / 192$ ochre, the $B g l \mathrm{II}-X b a \mathrm{I}$ fragment of pSVL-P29 $\Delta 5^{\prime}$ and the $B g / I I-E c o$ RI fragment of pBHE-P29 $\Delta 5^{\prime}$ were replaced by the corresponding fragments containing the ochre mutation.

\section{Transfection of COS and BHK-21 cells}

COS cells were transfected with pSVL-derived vectors and BHK-21 cells with pBHE-derived vectors plus pSV2pac DNA [8] using the calcium phosphate technique

Abbreviations used: MPR-46, mannose 6-phosphate receptor $\left(M_{\mathrm{r}} 46000\right)$; IGF, insulin-like growth factor; DSS, disuccinimidyl suberate; PAGE, polyacrylamide-gel electrophoresis.

* To whom correspondence should be addressed. 
$[9,10]$. In pSVL constructs the inserted DNA was under the control of the SV40 late promoter; in pBHE constructs it was under that of the SV40 early promoter. COS cells were used for metabolic labelling $24 \mathrm{~h}$ after transfection. BHK cells were grown for 2-3 weeks in the presence of $5 \mu \mathrm{g}$ of puromycin $/ \mathrm{ml}$ followed by isolation of stably-transfected clones.

\section{Microinjection of cRNA in oocytes}

P29 cDNA inserted into the EcoRI site of pGEM (Promega Biotec) was transcribed using SP6 polymerase and purified as described [10]. RNA (25 ng) in $50 \mathrm{nl}$ of water was injected into Xenopus laevis oocytes (stage V) as described [11]. The oocytes were maintained in Barth's medium containing Cefuroxim $(40 \mu \mathrm{g} / \mathrm{ml})$ and used for metabolic labelling $2.5 \mathrm{~h}$ after injection.

\section{Metabolic labelling and preparation of cell extracts}

Between eight and ten oocytes were labelled for $48 \mathrm{~h}$ with $7 \mathrm{MBq}$ of $\left[{ }^{35} \mathrm{~S}\right]$ methionine (specific radioactivity $\geqslant 24.6 \mathrm{TBq} / \mathrm{mmol}$ ) in $150 \mu \mathrm{l}$ of Barth's medium [11]. Cells were washed 3 times with $500 \mu$ l of Barth's medium and stored at $-70^{\circ} \mathrm{C}$. Subconfluent cultures of COS and BHK-21 cells on $6 \mathrm{~cm}$ Petri dishes were labelled for $16-20 \mathrm{~h}$ with $1.85 \mathrm{MBq}$ of $\left[{ }^{35} \mathrm{~S}\right]$ methionine as described [12], and collected by scraping.

For analysis of secreted proteins, the labelling media were subjected to ammonium sulphate precipitation $(0.5 \mathrm{~g} / \mathrm{ml}$ of medium) and dialysed against $10 \mathrm{~mm}$-Tris/ $\mathrm{HCl}, \mathrm{pH} \mathrm{7.0/150} \mathrm{mM-NaCl}$.

Soluble material was extracted from two oocytes or from cells ( $6 \mathrm{~cm}$ culture dish) with $0.8 \mathrm{ml}$ of $0.1 \mathrm{M}$-sodium acetate, $\mathrm{pH} 6.0,0.2 \mathrm{M}-\mathrm{NaCl}, 1 \mathrm{~mm}$-phenylmethanesulphonyl fluoride, $5 \mathrm{~mm}$-iodoacetamide and $1 \mathrm{~mm}$ EDTA. After sonication and centrifugation at $100000 \mathrm{~g}$ for $30 \mathrm{~min}$ at $4^{\circ} \mathrm{C}$, the supernatant (soluble fraction) was collected and the pellet was sonicated in $0.25 \mathrm{ml}$ of buffer A $[0.5 \%(\mathrm{w} / \mathrm{v})$ Triton X-100, $50 \mathrm{~mm}$-imidazole, $\mathrm{pH} 7.0$, $150 \mathrm{~mm}-\mathrm{NaCl}$, incubated for $15 \mathrm{~min}$ on ice and centrifuged as above. The resulting supernatant is referred to as membrane extract. The soluble fraction was subjected to acetone precipitation and redissolved in $0.25 \mathrm{ml}$ of buffer A prior to phosphomannan affinity-chromatography.

\section{Phosphomannan affinity-chromatography}

Phosphomannan-Sepharose $(300 \mu l)$ [13] in a Pasteur pipette was equilibrated with $50 \mathrm{~mm}$-imidazol $/ \mathrm{HCl}$, pH 7.0, $150 \mathrm{~mm}-\mathrm{NaCl}, 5 \mathrm{~mm}$-sodium $\beta$-glycerophosphate, $0.5 \mathrm{mg}$ of bovine serum albumin $/ \mathrm{ml}$ and $10 \mathrm{mM}-\mathrm{MgCl}_{2}$ (buffer B). Dialysed medium, soluble fraction or membrane extract $(0.1 \mathrm{ml}$ each) were adjusted to $10 \mathrm{~mm}$ $\mathrm{MgCl}_{2}$ and bound to the column for $15 \mathrm{~min}$ at $4^{\circ} \mathrm{C}$. The column was sequentially eluted with $0.05 \%(\mathrm{w} / \mathrm{v})$ Triton $\mathrm{X}-100$ in buffer B, 5 mM-glucose 6-phosphate in buffer B/ $0.05 \%$ Triton X-100 and $5 \mathrm{~mm}$-mannose 6-phosphate in buffer $\mathrm{B} / 0.05 \%$ Triton X-100.

\section{Chemical cross-linking with disuccinimidyl suberate (DSS)}

To enrich metabolically-labelled truncated MPR-46 secreted from transfected BHK cells, the labelling medium was dialysed against $0.1 \mathrm{M}$-sodium phosphate, $\mathrm{pH} 7.0$, and passed over phosphomannan-Sepharose as above using buffer B containing $0.1 \mathrm{M}$-sodium phosphate, $\mathrm{pH} 7.0$, instead of imidazole and $\mathrm{NaCl}$. The receptor- containing eluate was adjusted to $0.6 \mathrm{~mm}$-DSS using a $30 \mathrm{~mm}$ stock solution in dimethyl sulphoxide. Controls received dimethyl sulphoxide only. After $15 \mathrm{~min}$ at $37^{\circ} \mathrm{C}$, the reaction was quenched by adding Tris $/ \mathrm{HCl}$, pH 7.4, to $50 \mathrm{~mm}$.

\section{Immunoprecipitation of MPR-46}

Cell extracts, labelling media or eluates from the phosphomannan-Sepharose $(0.8 \mathrm{ml})$ were mixed with $0.64 \mathrm{ml}$ of $10 \mathrm{~mm}$-Tris/ $\mathrm{HCl}, \mathrm{pH} \mathrm{7.4,} 150 \mathrm{~mm}-\mathrm{NaCl}, 1 \%$ (w/v) Triton X-100, 0.5\% (w/v) sodium deoxycholate, $0.2 \%(\mathrm{w} / \mathrm{v}) \mathrm{SDS}, 10 \%(\mathrm{w} / \mathrm{v})$ bovine serum albumin, $1 \mathrm{~mm}$-phenylmethanesulphonyl fluoride, $1 \mathrm{~mm}$-EDTA and $5 \mathrm{~mm}$-iodoacetamide. The samples were incubated with $2 \mathrm{mg}$ of Immunoprecipitin (Bethesda Research Laboratories, Inc., Gaithersburg, MD, U.S.A.) at $4^{\circ} \mathrm{C}$ for $30 \mathrm{~min}$ and centrifuged for $60 \mathrm{~min}$ at $50000 \mathrm{~g}, 4^{\circ} \mathrm{C}$. The supernatant was incubated for $1 \mathrm{~h}$ with $2 \mu \mathrm{l}$ of antiserum against human MPR-46 and $4 \mathrm{mg}$ of pretreated Immunoprecipitin [14]. The immune complexes were washed as described [14] and solubilized in sample buffer for SDS/polyacrylamide-gel electrophoresis (PAGE) containing $10 \mathrm{~mm}$-dithiothreitol and $5 \mathrm{~mm}-$ EDTA.

\section{Treatment with glycosidases}

MPR-46 was isolated by immunoprecipitation and treated with 1 munit of endoglucosaminidase $H$ (Boehringer-Mannheim) or 100 munit of glycopeptidase $F$ (Boehringer-Mannheim) for $15 \mathrm{~h}$ at $37^{\circ} \mathrm{C}$ as described [4].

\section{Polyacrylamide-gel electrophoresis}

SDS/PAGE under reducing conditions, fluorography and solubilization of gel pieces for scintillation counting were done as described [15-17]. $\left[{ }^{14} \mathrm{C}\right]$ Methylated protein standards were from New England Nuclear.

\section{RESULTS}

\section{Expression systems}

The expression of the receptor cDNA was examined in three systems. For transient expression in Xenopus oocytes, capped cRNA obtained by transcription in vitro was used; for transient expression in COS cells and for stable expression in BHK-21 cells, pSVL-derived constructs and pBHE-derived constructs respectively were used. To analyse expression of the receptor, the cells were metabolically labelled, and the receptor was immunoprecipitated from the soluble and the membrane fractions of the cells as well as from the labelling medium.

\section{Expression of wild-type MPR-46}

cRNA transcribed from the cDNA clone P29 for MPR-46 [6] was microinjected into Xenopus oocytes followed by labelling with $\left[{ }^{35} \mathrm{~S}\right]$ methionine. The membrane extract of the oocytes contained immunoreactive MPR-46 (Fig. 1 $a$, wt). Two forms of MPR-46 were observed after reducing SDS/PAGE. The major form corresponds to the monomer of MPR-46, whereas the less abundant form represents a dimer, according to its apparent molecular mass. In contrast with the noncovalent dimer described earlier [4], this dimer was SDSresistant even under reducing conditions. Since it was observed in varying amounts mainly in oocytes (de- 

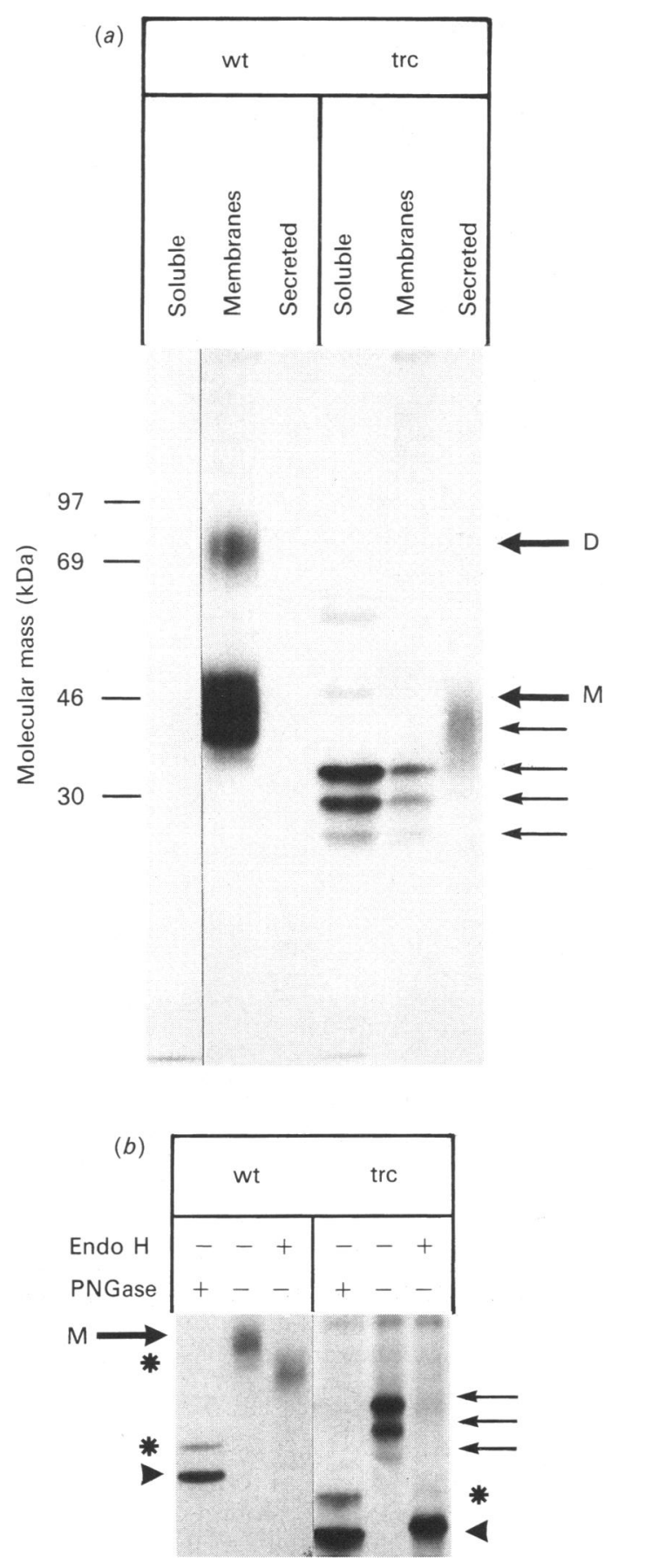

Fig. 1. Expression of human wild-type (wt) and truncated (trc) MPR-46 in Xenopus oocytes

cRNA coding for MPR-46 was injected into oocytes. (a) After labelling with $\left[{ }^{35}\right.$ S]methionine, MPR - 46 was immunoprecipitated from a soluble cell extract, detergent-solubilized membranes and labelling medium (Secreted). The immunoprecipitates were analysed by SDS/PAGE (10\% polyacrylamide) and fluorography. (b) The immunoprecipitates of wild-type MPR-46 from membranes and truncated MPR-46 from the soluble cell extract were treated with glycopeptidase F (PNGase) or endoglucosaminidase $\mathrm{H}$ (Endo $\mathrm{H}$ ) followed by SDS/PAGE. The part of the fluorogram containing immunoreactive bands is shown. Control experiments have shown that the minor product of PNGase digestion (upper band) can be converted into the final product (lower band) upon prolonged pending on the experiment, 10-30\% of total MPR-46), but less in other cell types (see below, Fig. 2), we believe that it is an artefact created during the membrane preparation. (The SDS-resistant dimer is most likely associated via the cytosolic tail, since a less SDSresistant dimer was observed with the truncated receptor described below.) In mock-injected oocytes, no immunoreactive MPR-46 was detectable (results not shown).

Transfection of COS cells with pSVL-P29 resulted only in a 2-fold increase in the amount of immunoreactive receptor as compared to mock-transfected cells (results not shown). Since the GC-rich sequences in the $5^{\prime}$ untranslated region of P29 were thought to impair expression, we deleted the $5^{\prime}$ end using exonuclease III. The product (P29 $\left.\Delta 5^{\prime}\right)$ contained only seven nucleotides upstream of the start methionine. Expression of the 5'deleted receptor cDNA in COS and BHK cells resulted in a greater than 20-fold increase in immunoreactive MPR-46 as compared to mock-transfected controls (Fig. 2, wt).

The wild-type receptor was exclusively associated with the membranes of oocytes, COS and BHK cells (Figs. $1 a$ and 2), contained mostly oligosaccharides resistant to endoglucosaminidase $\mathrm{H}$ and yielded a major $M_{\mathrm{r}} 27000$ product after deglycosylation with glycopeptidase $\mathrm{F}$ (shown for oocytes in Fig. 1b).

\section{Expression of a truncated soluble form of MPR-46}

A stop codon was introduced into the receptor cDNA by changing the codon of Leu-192 (TTA) to an ochre codon (TAA). Leu-192 represents the second amino acid of the predicted membrane-spanning domain of the receptor [6]. Therefore, expression of the mutated receptor cDNA was expected to result in the synthesis of soluble polypeptides which correspond to the ectoplasmic domain of MPR-46. Consistent with this prediction, the truncated receptor was recovered in either the secretions or in the soluble cell extract of oocytes, COS and BHK cells (Figs. I $a$ and 2, trc). In the mammalian cells (COS and BHK), secretion of the newly-synthesized truncated receptor occurred rapidly, so that immunoreactive material was not detectable in the cells. In oocytes only, most (76-100\%, depending on the experiment) of the truncated receptor was retained intracellularly during the $48 \mathrm{~h}$ labelling period. Two major bands and one minor band of MPR-46 were present in the soluble cell extract from oocytes (thin arrows in Fig. $1 a$, trc). To investigate whether these forms represent different polypeptides or glycosylation variants, the immunoprecipitates were deglycosylated with glycopeptidase F (Fig. 1b, PNGase). Deglycosylation resulted in a major $M_{\mathrm{r}} 18000$ product (arrowhead in Fig. $1 b$ ), indicating that the three forms were derived from the same core protein, but differed in the number of oligosaccharides. To investigate where in the secretory pathway of oocytes the truncated receptor had accumulated, the immunoprecipitates were treated with endoglucosaminidase $H$. The oligosaccharides of the intracellularly-retained truncated receptor were completely sensitive to endoglucosaminidase $\mathrm{H}$ (Fig. 1b) suggesting that they were high-mannose

incubation (not shown). Arrows: wild-type (bold) and truncated (thin) MPR-46; asterisks: partially deglycosylated MPR-46; arrowheads: unglycosylated MPR-46; M, monomer; $\mathrm{D}$, dimer. 

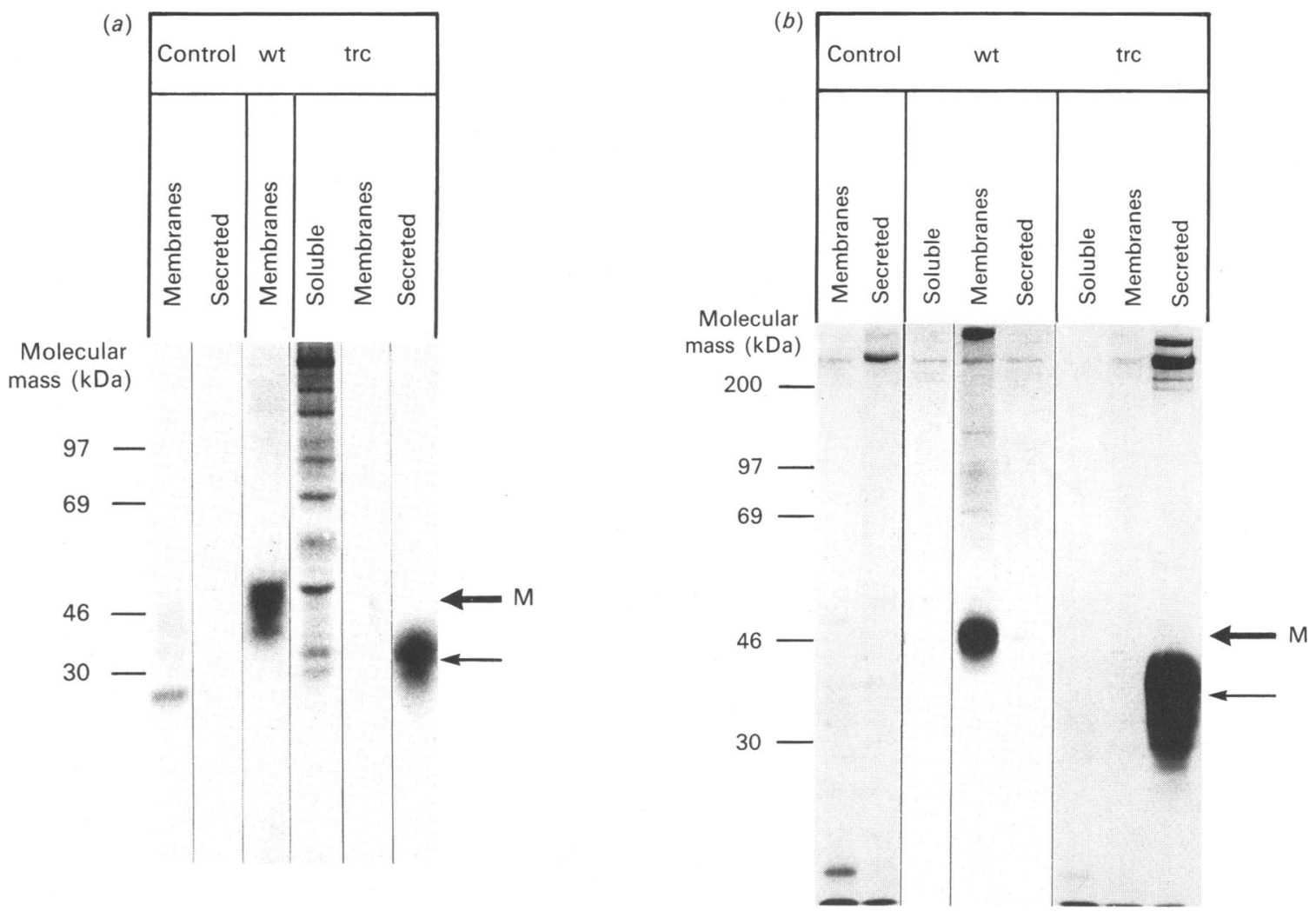

Fig. 2. Expression of human wild-type (wt) and truncated (trc) MPR-46 in (a) COS and (b) BHK cells

Transfected cells were labelled with $\left[{ }^{35}\right.$ S]methionine. Medium (Secreted) and cell extracts were analysed. A soluble cell extract and a detergent extract (Membranes) were prepared as described in the Materials and methods section. Immunoprecipitates were analysed by SDS/PAGE (10\% gel) and fluorography. Bold arrows indicate wild-type, thin arrows truncated MPR-46. M, monomer.

forms that had not left the endoplasmic reticulum. In contrast, the oligosaccharides of the truncated receptor secreted from oocytes, COS and BHK cells resembled the wild-type MPR-46. They were largely resistant to endoglucosaminidase $\mathrm{H}$ (shown for wt in Fig. $1 b$ ), suggesting that they had been partly processed to complex-type forms during their passage through the Golgi complex.

\section{Binding of wild-type and truncated MPR-46 to phosphomannan-Sepharose}

The ability of wild-type and truncated MPR-46 to bind ligands was studied using immobilized phosphomannan as an affinity matrix. The wild-type MPR-46 extracted from membranes of oocytes and BHK cells as well as the intracellularly retained (oocytes) and secreted (COS and BHK cells) forms of the truncated MPR-46 bound to phosphomannan-Sepharose. They were eluted by the specific ligand mannose 6-phosphate, but not by the carbohydrate analogue glucose 6-phosphate (Fig. 3). A total of $76-86 \%$ and $96 \%$ of wild-type receptor from oocytes and BHK cells respectively bound to phosphomannan-Sepharose. The amount of binding was $67-71 \%$ for the truncated receptor in oocytes, $85 \%$ in BHK cells and $98.3 \%$ in COS cells, suggesting similar efficiency of phosphomannan binding by wild-type and truncated MPR-46. These results show that receptor polypeptides lacking the transmembrane and cytosolic domains fold to a ligand-binding conformation.

\section{Quaternary structure of truncated MPR-46}

The ability of truncated MPR-46 to form oligomers was investigated by chemical cross-linking with the bifunctional reagent DSS. We found that the truncated MPR-46 polypeptides secreted by BHK cells exist as dimers (Fig. 4) as described for wild-type receptors [4]. With the cross-linking conditions used, no higher oligomers of the truncated MPR-46 were detectable. These data indicate that the MPR-46 dimer is stabilized at least partly by interactions between portions of the $N$-terminal ectoplasmic domain.

\section{DISCUSSION}

Wild-type human MPR-46 expressed in Xenopus oocytes and in heterologous mammalian cells (COS and BHK) was indistinguishable from the receptor synthesized in human cells with regard to (i) molecular mass of the polypeptide, (ii) association with membranes as an integral protein, (iii) $N$-linked glycosylation, the oligosaccharides being largely processed to complex-type forms, and (iv) binding to an affinity matrix in a mannose6-phosphate-dependent manner. 


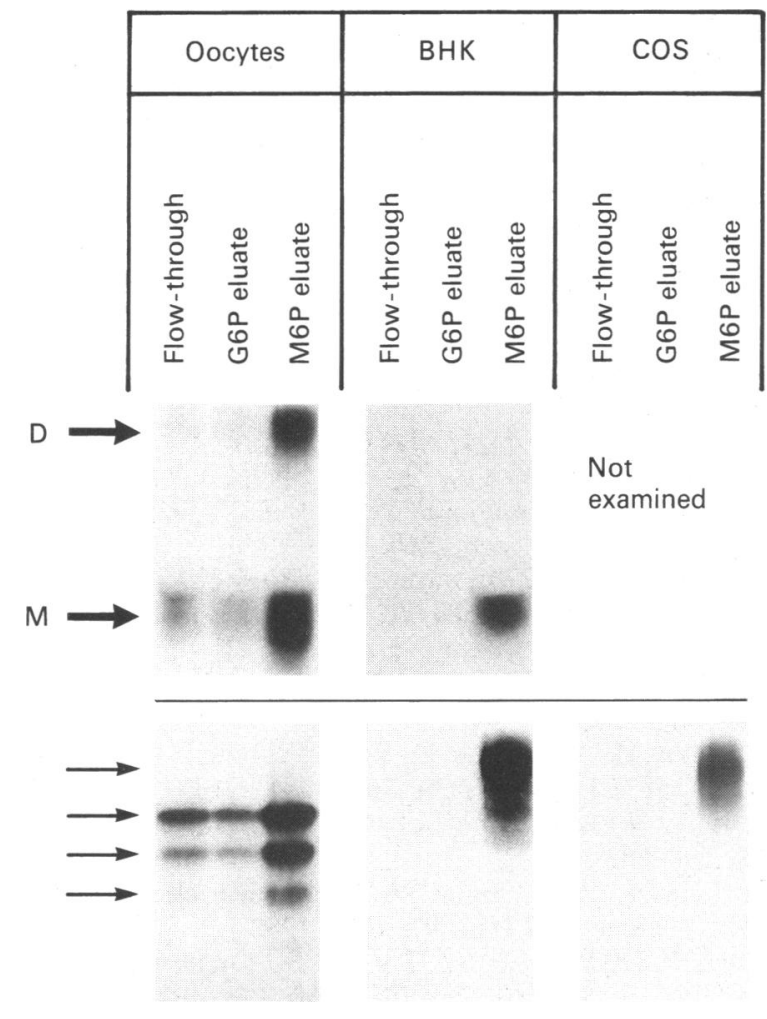

Fig. 3. Binding of $\left[{ }^{35}\right.$ S $]$ methionine-labelled wild-type and truncated MPR-46 to a phosphomannan-affinity matrix

For analysis of wild-type receptor (top panel), detergent extracts were prepared from oocytes and BHK cells. COS cell extracts were not examined. For analysis of the truncated receptor (bottom panel), the soluble cell extract of oocytes or the medium of BHK and COS cells were used. The samples were applied to the affinity column and eluted sequentially with glucose 6-phosphate (G6P) and mannose 6-phosphate (M6P). The receptor polypeptides were immunoprecipitated from the fractions containing the unbound material (Flow-through) and the eluates with glucose 6-phosphate and mannose 6-phosphate, and analysed by SDS/PAGE (10\% gel) and fluorography. The bold arrows show the wild-type MPR-46 [monomer (M) and dimer (D)], while thin arrows indicate the truncated MPR-46 protein. The part of the fluorogram containing immunoreactive material is shown. Dimers are not observed for the truncated MPR-46 (compare Fig. $1 a$ and Fig. 2) nor for receptor mutants that lack the $C$-terminal half of the cytoplasmic tail (not shown).

Truncated human MPR-46, which lacks the $C$-terminal portion beyond amino acid 192, was expressed as a soluble protein in oocytes and was secreted from mammalian cells. This finding corroborates the position of the membrane-spanning segment (ainino acids 191-209), which had been predicted by limited proteolysis studies and by analysis of the hydrophobicity profile of human MPR-46 [4,6].

Secretion of truncated membrane proteins lacking the membrane-spanning domain has been reported previously for low-density-lipoprotein receptor and for viral envelope proteins [18-20], whose main location is at the cell surface. In contrast, more than $95 \%$ of MPR-46 is found in internal membranes of cultured cells [4].
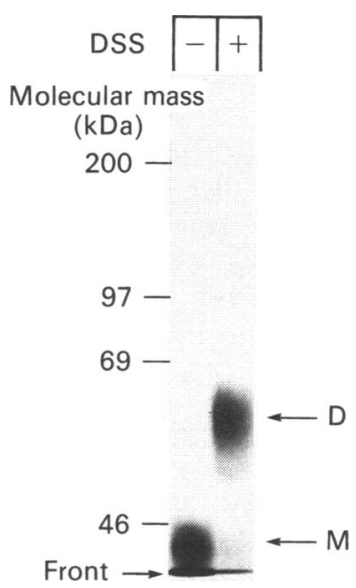

\section{Fig. 4. Cross-linking of truncated MPR-46}

Truncated MPR-46 from the medium of metabolicallylabelled transfected BHK cells was enriched by phosphomannan affinity-chromatography. After chemical crosslinking with $0.6 \mathrm{~mm}$-DSS, the receptor was immunoprecipitated. Fluorograms of SDS/PAGE $(7.5 \%$ gel) are shown. M, monomer; D, dimer.

Secretion of the truncated forms of MPR-46 indicates that the transmembrane domain is required for intracellular retention of the receptor. We believe that the truncated receptor is secreted by default. Its retention in oocytes may in part be due to incomplete glycosylation (lacking one or two $N$-linked oligosaccharides) and/or to a slow transport of secretory proteins in Xenopus oocytes. Slow transport of the lysosomal enzyme cathepsin D along the mannose 6-phosphate receptor-dependent pathway has been reported by Faust et al. [21].

Binding of truncated MPR-46 to phosphomannan ligands in a mannose 6-phosphate-dependent manner indicates that the ectoplasmic domain of MPR-46 constitutes an independent entity, which folds correctly and forms a functionally active protein, regardless of whether or not it is anchored in the membrane. Furthermore, acquisition of binding activity did not depend on complete $N$-glycosylation and processing of the $N$-linked oligosaccharides to complex forms (see binding of the incompletely glycosylated and non-processed receptor fragments accumulated in oocytes).

The results of the present study further show that the transmembrane and cytosolic domains are dispensible for the formation of homodimers of MPR-46. At present, it is not clear whether monomeric forms of MPR-46 are capable of binding ligands or whether dimerization is required for ligand binding. More detailed studies on the oligomerization of MPR-46 (A. Waheed, A. Hille, Junghans \& K. von Figura, unpublished work) indicate that an inability of MPR-46 to dimerize correlates strictly with a loss of binding activity, suggesting that MPR-46 is functionally active as a dimer.

The ectoplasmic domain of MPR-46 has a high degree of sequence similarity to each of the 15 non-identical contiguous repeats that constitute the ectoplasmic domain of the M6P/IGF II receptor [22]. If homodimers constitute the active form of MPR-46, it may be predicted that the mannose 6-phosphate binding site(s) of the 
M6P/IGF II receptor is also composed of two repeats. The repeats may reside in the same or two different receptor polypeptides.

This work was supported by the Deutsche Forschungsgemeinschaft (SFB 236) and the Fonds der Chemischen Industrie. The use of Professor B. Sakmann's microinjection facilities and the technical help of A. Draguhn for microinjection are gratefully acknowledged.

\section{REFERENCES}

1. von Figura, K. \& Hasilik, A. (1986) Annu. Rev. Biochem. 55, 167-193

2. Morgan, D. O., Edman, J. C., Standring, D. N., Fried, V. A., Smith, M. C., Roth, R. A. \& Rutter, W. J. (1987) Nature (London) 329, 301-307

3. von Figura, K., Gieselmann, V. \& Hasilik, A. (1985) Biochem. J. 225, 543-547

4. Stein, M., Braulke, T., Krentler, C., Hasilik, A. \& von Figura, K. (1987) Hoppe-Seyler's Z. Physiol. Chem. 368, 937-947

5. Hoflack, B. \& Kornfeld, S. (1985) J. Biol. Chem. 260, 12008-12014

6. Pohlmann, R., Nagel, G., Schmidt, B., Stein, M., Lorkowski, G., Krentler, C., Cully, J., Meyer, H. E., Grzeschik, K. H., Mersmann, G., Hasilik, A. \& von Figura, K. (1987) Proc. Natl. Acad. Sci. U.S.A. 84, 5575-5579

7. Nakamaye, K. L. \& Eckstein, F. (1986) Nucleic Acids Res. 14, 9679-9698

8. Vara, J. A., Portela, A., Ortin, J. \& Jimenez, A. (1986) Nucleic Acids Res. 14, 4617-4624
9. Pohlmann, R., Krentler, C., Schmidt, B., Schröder, W., Lorkowski, G., Cully, J., Mersmann, G., Geier, C., Waheed, A., Gottschalk, S., Grzeschik, K.-H., Hasilik, A. \& von Figura, K. (1988) EMBO J. 7, 2343-2350

10. Waheed, A., Gottschalk, S., Hille, A., Krentler, C., Pohlmann, R., Braulke, T., Hauser, H., Geuze, H. \& von Figura, K. (1988) EMBO J. 7, 2351-2358

11. Methfessel, C., Witzemann, V., Takahashi, T., Mishina, M., Numa, S. \& Sakmann, B. (1986) Pflügers Arch. 407, 577-588

12. Hasilik, A. \& Neufeld, E. F. (1980) J. Biol. Chem. 255, 4937-4945

13. Stein, M., Meyer, H. E., Hasilik, A. \& von Figura, K. (1987) Hoppe-Seyler's Z. Physiol. Chem. 368, 927-936

14. Lemansky, P., Gieselmann, V., Hasilik, A. \& von Figura, K. (1985) J. Biol. Chem. 260, 9023-9030

15. Laemmli, U.K. (1970) Nature (London) 227, 680-685

16. Bonner, W. M. \& Laskey, R. A. (1974) Eur. J. Biochem. 46, 83-88

17. Waheed, A., Hasilik, A. \& von Figura, K. (1982) Eur. J. Biochem. 123, 317-321

18. Lehrman, M. A., Russell, D. W., Goldstein, J. L. \& Brown, M. S. (1987) J. Biol. Chem. 262, 3354-3361

19. Gething, M. J. \& Sambrook, J. (1982) Nature (London) 300, 598-603

20. Florkiewicz, R. Z., Smith, A., Bergmann, J. E. \& Rose, J. K. (1983) J. Cell Biol. 97, 1381-1388

21. Faust, P. L., Wall, D. A., Perara, E., Lingappa, V. R. \& Kornfeld, S. (1987) J. Cell Biol. 105, 1937-1945

22. Lobel, P., Dahms, N. M., Breitmeyer, J., Chirgwin, J. M. \& Kornfeld, S. (1987) Proc. Natl. Acad. Sci. U.S.A. 84, 2233-2237

Received 2 September 1988/13 February 1989; accepted 16 February 1989 